\begin{tabular}{c} 
PEDIOMATERNAL \\
NURSING JOURNAL \\
Vol. 5, No. 1, Maret 2019 \\
Jediomaternal \\
Journal Homepage: https://e-journal.unair.ac.id/PMNJ// \\
\hline
\end{tabular}

Original Research

\title{
Dukungan Sosial sebagai Faktor Utama Pemberian Intervensi Gizi Spesifik pada Anak Usia 6-24 Bulan dengan Kejadian Stunting berbasis Transcultural Nursing
}

\author{
(Social Support as the Main Factor in Providing Specific Nutrition Interventions for Children \\ Aged 6-24 Months with Stunting Events based on Transcultural Nursing)
}

\author{
Vima Utya Cahyani, Esti Yunitasari, dan Retno Indarwati \\ Fakultas Keperawatan, Universitas Airlangga, Surabaya, Jawa Timur, Indonesia
}

\section{ARTICLE HISTORY \\ Received: March 18, 2019 \\ Accepted: April 30, 2019}

\section{KEYWORDS}

stunting; specific nutrition intervention; toddlers; transcultural nursing

\section{CORRESPONDING AUTHOR}

Vima Utya Cahyani vima.utya.cahyani2017@fkp.unair.ac.id Fakultas Keperawatan, Universitas Airlangga, Surabaya, Jawa Timur, Indonesia

\begin{abstract}
Introduction: Stunting is a chronic nutritional issue that happens in the world including Indonesia caused by local cultural factors. Madurese people are one of the races that closely live to their culture. Madurese people practice a culture that is related to nutrition intervention provision for toddlers. This study was aimed to analyse the factors related to specific intervention provision as an effort to prevent stunting from occurring to toddlers aged 6-24 months old.
\end{abstract}

Methods: This study used analytical design in Galis community health care December 2019. The population in this study were 160 mothers with toddlers aged 6-24 months old in which 115 of them were selected as sample based on purposive sampling. The inclusion criteria were the mothers who lived with their child in one house and caring for the child themselves. Exclusion criteria were mothers with a history of Special Economic Zone (SEZ) and mothers who were not present at the time of the study. The independent variables in this study were technological factor, religious and philosophical factor, social support factor, cultural value and lifestyle, political and legal factor, economic factor, and educational factor. Meanwhile, the dependant variable was the provision of specific nutritional interventions, namely colostrum, exclusive breastfeeding - breastfeeding up to 23 months accompanied by complementary foods, worm medicine, zinc supplements, iron, complete immunization, and diarrhoea prevention and treatment. The data were collected by questionnaires with Logistic Regression Analysis.

Results: The result of this study showed that social support is related to specific nutrition intervention provision with significance of $p=0.003$. Cultural values and life style are related to specific nutrition intervention provision with significance of $\mathrm{p}=0.048$.

Conclusion: According to this study, factors that give significant influence is social support consisting of instruction information and advice. Madurese people still believe that the most influential and experienced persons in child caring are grandmother, mother in law, and parents.

Cahyani, V. U., Yunitasari, E., \& Indarwati, R. (2019). Dukungan Sosial sebagai Faktor Utama Pemberian Intervensi Gizi Spesifik pada Anak Usia 6-24 Bulan dengan Kejadian Stunting berbasis Transcultural Nursing. Pediomaternal Nurs. J., 5(1), 77-88.

\section{PENDAHULUAN}

Stunting adalah masalah kurang gizi kronis yang disebabkan oleh asupan gizi kurang dalam waktu cukup lama akibat pemberian makanan yang tidak sesuai dengan kebutuhan gizi. Stunting dapat terjadi mulai masih janin dalam kandungan dan baru nampak saat anak berusia dua tahun (1). Stunting yang telah terjadi bila tidak diimbangi dengan catchup growth (tumbuh kejar) mengakibatkan menurunnya pertumbuhan. Masalah stunting merupakan masalah kesehatan masyarakat yang berhubungan dengan meningkatnya risiko kesakitan, kematian, dan hambatan pada pertumbuhan baik 
motoric maupun mental. Stunting dibentuk oleh growth faltering dan catch-up growth yang tidak memadai yang mencerminkan ketidakmampuan untuk mencapai pertumbuhan optimal, hal tersebut mengungkapkan bahwa kelompok balita yang lahir dengan berat badan normal dapat mengalami stunting bila pemenuhan kebutuhan selanjutnya tidak terpenuhi dengan baik (2)

Indonesia termasuk dalam 17 negara diantara 117 negara di dunia yang mempunyai masalah gizi tentang Stunting (3). Prevalensi balita di Indonesia sangat pendek menurun mulai tahun 2007 yaitu 18,8\%, tahun 2013 adalah 18\%, dan tahun 2018 menjadi $11,5 \%$. Sementara prevalensi balita pendek meningkat mulai tahun 2007 sejumlah 18,0\%, tahun 2013 sejumlah 19,2\%, dan yaitu 2018 sejumlah $19,3 \%$ (4). Dapat disimpulkan bahwa pada tahun 2013 balita sangat pendek dan pendek berjumlah 37,2\% sedangkan pada tahun 2018 sejumlah 30,8\%. Berdasarkan Studi Pendahuluan data di Dinkes Kabupaten Bangkalan, didapatkan pada tahun 2018 terdapat 16,84\% (902 balita) yang mengalami indikator bayi pendek dan sangat pendek dimana paling banyak terjadi di Desa Galis sebanyak 20,6\% (186 balita), Desa Bangkalan sebanyak 12,8\% (116 balita), disusul desa Arosbaya sebanyak 10,7\% (97 balita).

Masalah balita pendek menggambarkan adanya masalah gizi kronis, dipengaruhi dari kondisi ibu atau calon ibu, masa janin, dan masa bayi atau balita, termasuk penyakit yang diderita selama balita (5). Kekurangan atau kelebihan zat gizi pada periode $0-2$ tahun umumnya ireversibel dan akan berdampak pada kualitas hidup jangka pendek dan jangka panjang. Dampak stunting akan mempengaruhi perkembangan otak jangka panjang yang selanjutnya pada kemampuan kognitif dan prestasi pendidikan, dimana dampak tersebut dipengaruhi oleh beberapa faktor (6). Salah satu pencegahan stunting adalah dengan pemberian intervensi gizi spesifik. . Intervensi gizi spesifik ini dimulai sejak hari pertama ibu hamil, kelahiran bayi sampai anak berusia 2 tahun. Periode ini merupakan periode 1000 hari pertama kehidupan manusia, yaitu 270 hari selama kehamilan dan 730 hari pada kehidupan pertama bayi yang dilahirkan. Periode ini telah dibuktikan secara ilmiah merupakan periode yang menentukan kualitas kehidupan dan merupakan periode sensitive karena dampak yang ditimbulkan akan bersifat permanen dan tidak dapat dikoreksi (7).

Ada dua yang memengaruhi status gizi anak, faktor tersebut adalah faktor langsung dan tidak langsung Budaya termasuk salah satu faktor tidak langsung yang bisa menyebabkan stunting. Budaya, tradisi, atau kebiasaan yang ada seperti pantangan makan, dan pola makan yang salah dapat mengakibatkan munculnya masalah gizi terutama bagi balita (8). Hal ini dapat berdampak terhadap pertumbuhan dan perkembangan balita yang merupakan salah satu faktor tidak langsung yang memengaruhi sikap ibu dalam menjalani masa kehamilan, menjalani proses persalinan, serta dalam pola asuh balita (9). Analisis masalah dengan pendekatan budaya diperlukan sebagai upaya untuk mengidentifikasi hubungan masalah kesehatan sesuai dengan latar belakang budaya terhadap prevalensi stunting di Puskesmas Galis Kabupaten Bangkalan menggunakan Teori Transcultural Nursing.

Model teori Transcultural lebih diaplikasikan pada keperawatan berbasis budaya dibandingan dengan model keperawatan lain. Upaya dan penelitian yang pernah dilakukan belum menganalisis faktor-faktor yang berhubungan dengan pemberian gizi spesifik pada penanganan stunting berbasis Transcultural Nursing pada Suku Madura, sedangkan dimensi budaya Madura masih sangat kuat, oleh karena itu analisis masalah dengan pendekatan Transkuktural sangat dibutuhkan. Berdasarkan uraian yang telah dijelaskan sebelumnya sehingga perlu dilakukan penelitian untuk mngetahui apa saja faktor yang berhubungan dengan pemberian intervensi gizi spesifik pada anak usia 6-24 bulan dengan kejadian stunting Berbasis Tanscultural Nursing di wilayah kerja Puskesmas Galis Kabupaten Bangkalan.

\section{METODE}

\subsection{Desain}

Penelitian yang dilaukan merupakan Jenis penelitian descriptive analytic dengan pendekatan cross sectional

\subsection{Populasi, sampel, dan sampling}

Populasi dalam penelitian ini adalah ibu yang mempunyai anak usia 6-24 bulan di Wilayah Kerja Puskesmas Galis Bangkalan sebanyak 160 orang dan didapatkan 115 orang ibu dengan menggunakan rumus slovin. Kriteria Insklusi adalah Ibu yang merawat sendiri anaknya, tinggal satu rumah dengan anaknya, ibu yang tinggal dengan orang tua tau nenek ataupun tidak. Kriteria Eksklusi adalah anak usia 6 sampai 24 bulan yang mempunyai riwayat BBLR, anak dengan ibu riwayat KEK (Kekurangan Energi Kronis), Ibu yang tidak ada ditempat saat dilakukan penelitian, anak usia 6-24 bulan dengan penyakit penyerta.

\subsection{Variabel}

Variabel independen (bebas) dalam penelitian ini adalah Transcultural Nursing yaitu faktor teknologi (akses tahap teknologi informasi, akses pada media pers, akses pada alat elektronik, di lingkungan dan akses pada pelyanan kesehatan), faktor religious \& filosofi (praktik keagamaan, konsultasi dukun, arti hidup, kekuatan individu, kepercayaan, spiritualitas dan kesehatan, nilai personal, norma dan kepercayaan agama, kebebasan bberpikir dan berekspresi, nilai institusional, hasil dan prioritas, perab sosial, komunikasi antar institusi, komunikasi intrasektor), faktor dukungan sosial (dukungan emosional berupa ungkapan empati, kepedulian, dan perhatian terhadap orang bersangkutan, dukungan penghargaan berupa ungkapan hormat atau 
penghargaan positif untuk orang lain, dorongan maju atau persetujuan dengan gagasan perasaan individu dan pengabdian positif orang dengan orang lain misalnya orang itu kurang mampu atau lebih buruk keadaanya atau menambah harga diri, Dukungan informatif berupa pemberian, saran, informasi, petunjuk, dukungan instrumental berupa bantuan misalnya dengan memberi pinjaman uang kepada orang yang membutuhkan atau menolong dengan memberi pekerjaan pada orang yang tidak punya pekerjaan), faktor nilai budaya \& gaya hidup (buadaya sbagai ide-ide, komunikasi, tindakan, kebiasaan, kepercayaan, nilai-nilai, dan adat istiadat dari kelompok ras, etnik, agama atau sosial), faktor politik \& legal (kebijakan pemerintah dan kebijakan dan aturan adat di masyarakat), faktor ekonomi (jumlah pendapatan keluarga perbulan), faktor pendidikan (pendidikan formal ibu).

Variabel dependen dalam penelitian ini adalah pemberian gizi spesifik yaitu pemberian kolostrum, ASI eksklusif, ASI sampai 23 bulan didampingi makanan pendamping, penyediaan obat cacing dan suplemen zink, pemberian zat besi dan imunisasi lengkap, pencegahan dan pengobatan diare

\subsection{Instrumen}

Kuesioner faktor teknologi meliputi pertanyaan tentang sarana dan prasarana dalam menyelesaikan masalah pemberian Gizi spesifik pada balita yang sudah diuji validitas dan reliabilitas terdiri dari 10 pertanyaan closed ended dengan tipe dichotomy question yaitu jawaban terbatas ya dan tidak. Jawaban ya dinilai 2 dan tidak dinilai 1 untuk pertanyaan positif dan tidak diberikan nilai 2, iya diberikan nilai 1 pada pertanyaan negatif. Skor Faktor Teknologi $>75 \%=$ baik, Skor $55-75 \%=$ cukup, Skor $<55 \%=$ Kurang.

Kuesioner faktor religius \& filosofi meliputi pertanyaan tentang adanya agama yang dianut, cara pandang terhadap penyakit, dan cara pengobatan/ kebiasaan agama yang mempunyai efek terhadap kesehatan yang telah diuji validitas dan reliabilitas. Panduan wawancara menggunakan skala likert, dengan pilihan jawaban yang terdiri dari sangat setuju, setuju, tidak setuju, dan sangat tidak setuju. Skore positif jika $\mathrm{T} \geq$ mean, skore negative apabila $\mathrm{T}<$ mean.

Kuesioner dukungan sosial meliputi dukungan sosial dalam bentuk dukungan emosional, penghargaan, informatif dan instrumental yang telah diuji validitas dan reliabilitas. Panduan wawancara diukur dengan skala likert, dengan pilihan jawaban terdiri dari selalu, sering, jarang, tidak pernah. Skor $>75 \%=$ Faktor sosial baik, Skor 55-75\%= Faktor sosial cukup, Skor $<55 \%=$ Faktor sosial kurang.

Kuesioner nilai budaya \& gaya hidup meliputi panduan wawancara diukur dengan skala likert, dengan pilihan jawaban terdiri dari sangat setuju, setuju, tidak setuju, dan sangat tidak setuju. Kuesioner nilai budaya dan gaya hidup berisi sesuatu keyakinan yang dirumuskan dan ditetapkan oleh penganut budaya yang baik dan buruk. Skor Positif jika $\mathrm{T} \geq \mathrm{T}$ mean merupakan Nilai budaya \& gaya hidup positif dan skor negatif jika $\mathrm{T}<\mathrm{T}$ mean: Nilai budaya \& gaya hidup negative.

Kuesioner politik \& legal meliputi pertanyaan tentang kebijakan dan peraturan tentang pemberian gizi spesifik yang sudah dilakukan uji validitas dan reliabilitas. Panduan wawancara menggunakan skala likert, dengan pilihan jawaban yang terdiri dari ya dan tidak. . Jika responden menjawab ya diberikan nilia 2 dan jawaban tidak diberi nilai 1untuk pertanyaan positif dan tidak diberikan nilai 2, iya diberikan nilai 1 pada pertanyaan negatif. Skor Positif jika $\mathrm{T} \geq \mathrm{T}$ mean merupakan faktor politik \& legal positif, dan skor negatif jika $\mathrm{T}<\mathrm{T}$ mean: Faktor politik \& legal negatif.

Kuesioner faktor ekonomi teridiri dari 2 pertanyaan yang menggunakan pilihan jawaban berupa ya dan tidak dan telah diuji validitas dan reliabilitas. Jika jawaban ya diberi skor 2 dan jawaban tidak diberi skor 1 untuk pertanyaan positif. Faktor ekonomi tinggi jika nilai = 2 (sama dengan atau lebih dari UMR), dan ekonomi rendah jika nilai $=1$ (dibawah UMR).

Kuesioner faktor pendidikan dibagi menjadi Tidak sekolah/tidak tamat pendidikan dasar (tidak sekolah/tidak tamat SD), pendidikan dasar (tamat SD sederajat/tamat SMP sederajat), pendidikan menengah (tamat SMA sederajat), dan Pendidikan tinggi (akademi/perguruan tinggi). Pendidikan dasar diberi nilai 1, Pendidikan menengah diberi nilai 2, dan Pendidikan tinggi diberi nilai 3, pendidikan Perguruan Tinggi diberi nilai 4.

Kuesioner pemberian intervensi gizi spesifik berisi pertanyaan tentang tindakan yang dilakukan seorang ibu dalam memberikan gizi spesifik pada balita (Pemberian kolostrum, pemberian ASI eksklusif, pemberian ASI sampai 23 bulan didampingi makanan pendamping ASI, Penyediaan obat cacing, penyediaan suplemen zink, pemberian zat besi, pemberian Imunisasi lengkap, pencegahan dan pengobatan diare) yang telah diuji validitas dan reabilitas. Panduan wawancara diukur dengan cara memberikan pertanyaan-pertanyaan, dengan pilihan jawaban berupa: iya dan tidak. Jawaban iya dibrikan nilai 2 dan tidak diberikan nilai 1 untuk pertanyaan positif dan tidak diberikan nilai 2 , iya diberikan nilai 1 pada pertanyaan negatif.

Kuesioner demografi berisi panduan wawancara data demografi merupakan pertanyaan untuk mengetahui informasi secara umum pada respinden. Ada 9 pertanyaan yang terdiri umur ibu, umur anak, jenis kelamin anak, jumlah anak, tinggi anak, jumlah anggota keluarga, bentuk keluarga, status perkawinan, bentuk keluarga, pekerjaan orang tua.

\subsection{Prosedur}

Mengurus surat-surat nilai dari Universitas, Bakesbanpol, Kemudian Dinkes dan Puskesmas. Kemudian melakukan koordinasi dengan pikhak Puskesmas Galis, menetukan responden dengan mengikuti kegiatan posyandu di Puskesmas Galis, mendatangi responden yang sesuai dengan kriteria insklusi yang telah ditentukan di posyandu dan 
secara door to door jika responden tidak hadir pada posyandu saat dilakukan peneltian. Kemudian peneliti kontrak waktu dengan responden, menjelaskan tujuan dan langkah dari penelitian pada masing-masing responden serta memberikan surat peretujuan (informed consent) menjadi responden penelitian untuk ditandatangani.

Peneliti menjelaskan cara pengisian lembar kuesioner, waktu yang dibutuhkan responden untuk mengisi kuesioner kurang lebih 5 menit. Peneliti membagikan kuesioner dan membantu menjelaskan dan memberikan pendampingan dalam menjawab pertanyaan pada responden yang kurang memahami pertanyaan. Setelah selesai kuesioner dikembalikan kepada peneliti untuk dicek apakah kuesioner sudah terisi semua dan sesuai pertanyaan atau belum. Pemberian sovenir sebagai tanda terima kasih atas kerjasama ibu dilakukan setelah pengisisan kuesioner. Hasil wawancara dan kuesioner yang telah terisi dicatat dalam lembar pengumpulan data, editing, coding, analis dan penyajian data. Masingmasing kegiatan dilakukan satu kali (tidak ada follow up) dalam satu waktu.

\subsection{Analisis}

Penelitian ini dilakukan dengan IBM SPSS Statistic 25 dengan uji Regresi Logistik dengan signifikansi $\mathrm{p}=0,05$.

\subsection{Ethical Clearance}

Penelitian ini telah dinyatakan lolos kaji etik dan mendapatkan sertifikat Ethical Approval dengan No. 1249-KEPK yang dikeluarkan oleh Komite Etik Penelitian Kesehatan Fakultas Keperawatan Universitas Airlangga pada tanggal 3 Jauari 2019.

\section{Hasil}

Pada analisis hubungan faktor teknologi dengan pemberian intervensi gizi spesifik [Tabel 1] menunjukan bahwa 115 responden yang memiliki anak usia 6-24 bulan sebagian besar memiliki pemanfaatan teknologi cukup sebanyak 70 orang $(60,9 \%)$ dengan pemberian intervensi gizi spesifik yang negatif yaitu sebanyak 43 orang $(37,4 \%)$. Sedangkan sebagian kecil memiliki pemanfaatan teknologi yang kurang yaitu 1 orang $(0,9 \%)$ dengan pemberian intervensi gizi spesifik yang negatif. Berdasarkan hasil Analisa statistik dengan $\alpha<0,05$ didapatkan hasil faktor teknologi $(p=0,068)$ tidak berhubungan dengan pemberian intervensi gizi spesifik di wlayah kerja Puskesmas Galis secara signifikansi $(\mathrm{p}>0,05)$.

Pada analisis hubungan faktor religious dan filosofis dengan pemberian intervensi gizi spesifik [Tabel 1] menunjukan bahwa 115 responden yang memiliki anak usia 6-24 bulan memiliki faktor religius dan filosofis yang tidak mendukung sebesar cukup sebanyak 58 orang $(50,4 \%)$ dengan pemberian intervensi gizi spesifik yang negatif yaitu sebanyak 39 orang $(33,9 \%)$. Sedangkan yang memiliki faktor religius dan filosofi mendukung sebanyak 57 orang
$(49,6 \%)$ dengan pemberian intervensi gizi spesifik yang positif sebanyak 39 orang $(33,9 \%)$. Berdasarkan hasil analisa statistik dengan $\alpha<0,05$ didapatkan hasil faktor religious dan filosofi $(p=0,704)$ tidak berhubungan dengan pemberian intervensi gizi spesifik di wlayah kerja Puskesmas Galis secara signifikansi $(\mathrm{p}>0,05)$.

Pada analisis hubungan faktor hubungan dukungan sosial dengan pemberian intervensi gizi spesifik [Tabel 1] menunjukan bahwa 115 responden yang memiliki anak usia 6-24 bulan sebagian besar memiliki dukungan sosial yang tidak mendukung sebesar cukup sebanyak 76 orang $(66,1 \%)$ dengan pemberian intervensi gizi spesifik yang negatif yaitu sebanyak 44 orang (38,3\%). Sedangkan paling sedikit terdapat 8 orang $(7,0 \%)$ responden yang mempunyai dukungan sosial yang kurang mendukung dengan pemberian intervensi gizi spesifik yang negatif. Berdasarkan hasil analisa statistik dengan $\alpha<0,05$ didapatkan hasil faktor dukungan sosial $(\mathrm{p}=0,003)$ berhubungan dengan pemberian intervensi gizi spesifik di wlayah kerja Puskesmas Galis secara signifikansi ( $p>0,05)$.

Pada analisis hubungan faktor nilai budaya dan gaya hidup dengan pemberian intervensi gizi spesifik [Tabel 1] menunjukan bahwa 115 responden yang memiliki anak usia 6-24 bulan sebagian memiliki faktor nilai budaya dan gaya hidup yang tidak mendukung sebanyak 63 orang $(54,6 \%)$ dengan pemberian intervensi gizi spesifik yang tidak baik yaitu sebanyak 40 orang $(34,8 \%)$. Sedangkan yang memiliki faktor nilai budaya dan gaya hidup yang mendukung sebanyak 52 orang $(45,2 \%)$ dengn pemberian intervensi gizi spesifik yang baik sebanyak 35 orang $(30,4 \%)$. Berdasarkan hasil analisa statistik dengan $\alpha<0,05$ didapatkan hasil faktor nilai budaya dan gaya hidup $(p=0,048)$ berhubungan dengan pemberian intervensi gizi spesifik di wlayah kerja Puskesmas Galis secara signifikansi ( $p>0,05)$.

Pada analisis hubungan faktor politik dan legal dengan pemberian intervensi gizi spesifik [Tabel 1] menunjukan bahwa 115 responden yang memiliki anak usia 6-24 bulan sebagian memiliki faktor politik dan legal yang mendukung sebanyak 62 orang $(53,9 \%)$ dengan pemberian intervensi gizi spesifik yang positif dari 62 orang tersebut sebanyak 33 orang $(28,7 \%)$. Sedangkan yang memiliki faktor politik dan gaya hidup yang tidak mendukung sebanyak 53 orang $(46,1 \%)$ dengn pemberin intervensi gizi spesifik yang negatif pada 53 orang tersebut sebanyak 28 orang $(24,3 \%)$. Berdasarkan hasil analisa statistik dengan $\alpha$ $<0,05$ didapatkan hasil faktor politik dan legal $(\mathrm{p}=0,640)$ Tidak berhubungan dengan pemberian intervensi gizi spesifik di wlayah kerja Puskesmas Galis secara signifikansi ( $p>0,05)$.

Pada analisis hubungan faktor ekonomi dengan pemberian intervensi gizi spesifik [Tabel 1] menunjukan bahwa 115 responden yang memiliki anak usia 6-24 bulan sebagian besar memiliki tingkat ekonomi rendah sebanyak 77 orang (67\%) dengan intervensi pemberian gizi spesifik yang postif 
Tabel 1. Deskripsi Tabel Hubungan Faktor-Faktor Transcultural Nursing dengan Pemberian Intervensi Gizi Spesifik

\begin{tabular}{|c|c|c|c|c|c|c|c|}
\hline \multirow{3}{*}{ Variabel } & \multirow{3}{*}{ Kategori } & \multicolumn{4}{|c|}{ Pemberian Intervensi Gizi Spesifik } & \multirow{3}{*}{$\Sigma(\%)$} & \multirow{3}{*}{$\mathbf{p}$} \\
\hline & & \multicolumn{2}{|c|}{ Negatif } & \multicolumn{2}{|c|}{ Positif } & & \\
\hline & & $\mathbf{n}$ & $\%$ & $\mathbf{n}$ & $\%$ & & \\
\hline \multirow{4}{*}{ Faktor teknologi } & Kurang & 1 & 0,9 & 0 & 0 & $1(0,9)$ & \multirow{4}{*}{0,068} \\
\hline & Cukup & 43 & 37,4 & 27 & 23,5 & $70(60,9)$ & \\
\hline & Baik & 13 & 11,3 & 31 & 27 & $44(38,2)$ & \\
\hline & Total & 57 & 49,6 & 58 & 50,4 & $115(100)$ & \\
\hline \multirow{4}{*}{$\begin{array}{l}\text { Faktor Religius } \\
\text { dan Filosofi }\end{array}$} & $\begin{array}{l}\text { Tidak } \\
\text { mendukung }\end{array}$ & 39 & 33,9 & 19 & 16,5 & $58(50,4)$ & \multirow{4}{*}{0,704} \\
\hline & Mendukung & 18 & 15,7 & 39 & 33,9 & $57(49,6)$ & \\
\hline & Total & 57 & 49,6 & 58 & 50,4 & $115(100)$ & \\
\hline & Kurang & 8 & 7 & 0 & 0 & $8(7)$ & \\
\hline \multirow{3}{*}{$\begin{array}{l}\text { Faktor Dukungan } \\
\text { Sosial }\end{array}$} & Cukup & 44 & 38,3 & 32 & 27,8 & $76(66,1)$ & \multirow{3}{*}{0,003} \\
\hline & Baik & 5 & 4,3 & 26 & 22,6 & $31(27)$ & \\
\hline & Total & 57 & 49,6 & 58 & 50,4 & $115(100)$ & \\
\hline \multirow{3}{*}{$\begin{array}{l}\text { Faktor Budaya } \\
\text { dan gaya hidup }\end{array}$} & $\begin{array}{l}\text { Tidak } \\
\text { mendukung }\end{array}$ & 40 & 34,8 & 23 & 20 & $63(54,8)$ & \multirow{3}{*}{0,048} \\
\hline & Mendukung & 17 & 14,8 & 35 & 30,4 & $52(45,2)$ & \\
\hline & Total & 57 & 49,6 & 58 & 50,4 & $115(100)$ & \\
\hline \multirow{3}{*}{$\begin{array}{l}\text { Faktor Politik } \\
\text { dan Legal }\end{array}$} & $\begin{array}{l}\text { Tidak } \\
\text { Mendukung }\end{array}$ & 28 & 24,3 & 25 & 21,7 & $53(46,1)$ & \multirow{3}{*}{0,640} \\
\hline & Mendukung & 29 & 25,2 & 33 & 28,7 & $62(53,9)$ & \\
\hline & Total & 57 & 49,6 & 58 & 50,4 & $115(100)$ & \\
\hline \multirow{3}{*}{ Faktor Ekonomi } & Rendah & 37 & 32,2 & 40 & 34,8 & $77(67)$ & \multirow{3}{*}{0,973} \\
\hline & Tinggi & 20 & 17,4 & 18 & 15,7 & 38 (33) & \\
\hline & Total & 57 & 49,6 & 58 & 50,4 & $115(100)$ & \\
\hline \multirow{5}{*}{$\begin{array}{l}\text { Faktor } \\
\text { Pendidikan }\end{array}$} & SD & 25 & 21,7 & 21 & 18,3 & $46(40)$ & \multirow{5}{*}{0,928} \\
\hline & SMP & 14 & 12,2 & 20 & 18,3 & $34(29,6)$ & \\
\hline & SMA & 15 & ‘13 & 8 & 17,4 & $23(20)$ & \\
\hline & $\begin{array}{l}\text { Perguruan } \\
\text { Tinggi }\end{array}$ & 3 & 2,6 & 9 & 7 & $12(10,4)$ & \\
\hline & Total & 57 & 49,6 & 58 & 7,8 & $115(100)$ & \\
\hline
\end{tabular}

Diandra 77 orang tersebut sebanyak 40 orang $(34,8 \%)$. Sedangkan yang memiliki tingkat ekonomi tinggi sebanyak 38 orang (33\%) dengan pemberian intervensi gizi spesifik yang kurang diantara 38 orang tersebut sebanyak 20 orang $(17,4 \%)$. Berdasarkan hasil analisa statistik dengan $\alpha<0,05$ didapatkan hasil faktor Puskesmas Galis secara signifikansi ( $\mathrm{p}>0,05)$.

Pada analisis hubungan faktor pendidikan dengan pemberian intervensi gizi spesifik [Tabel 1] menunjukan bahwa 115 responden yang memiliki anak usia 6-24 bulan sebagian memiliki tingkat pendidikan sekolah dasar (SD) sebanyak 46 orang (40\%) dengan pamberian intervensi gizi spesifik yang negatif rendah sebanyak 25 orang $(21,7 \%)$. Sedangkan yang paling sedikit adalah Perguruan Tinggi dengan pemberian intervensi giziz spesifik yang positif sebnyak 9 orang $(7,8 \%)$. Berdasarkan hasil analisa statistik dengan $\alpha<0,05$ didapatkan hasil faktor ekonomi ( $p=0,928)$ tidak berhubungan dengan pemberian intervensi gizi spesifik di wlayah kerja Puskesmas Galis secara signifikansi $(p>0,05)$.

\section{PEMBAHASAN}

4.1 Faktor Teknologi dengan pemberian intervensi gizi spesifik

Hasil penelitian variabel faktor teknologi menunjukan bahwa ibu yang menjadi responden mayoritas mempunyai pemanfaatkan faktor teknologi yang cukup, namun cenderung tidak baik dalam memberikan intervensi gizi spesifik. Dari uji regresi logistik, nilai kemaknaan dan korelasinya menunjukan tidak ada hubungan yang signifikan antara faktor teknologi dengan pemberian intervensi gizi spesifik. Hal ini disimpulkan bahwa faktor teknologi tidak mempunyai pengaruh terhadap pemberian intervensi gizi spesifik.

Penelitian ini tidak sesuai dengan penelitian (10) yang mengatakan bahwa faktor teknologi mempengaruhi pemberian Pola makan pada balita gizi kurang dan gizi buruk, karena kurang pemanfaatan teknologi dapat mengakibatkan Pola pemberian makanan yang tidak susuai. Menurut teori transcultural nursing faktor teknologi merupakan salah satu faktor yang mempengaruhi perilaku individu berdasarkan budaya (11). Pada penelitian ini, meskipun pemanfaatan teknologi cukup namun kurang baik dalam pemberian intervensi gizi spesifik. Peneliti beranggapan bahwa faktor budaya yang kuat telah mempengaruhi penerapan informasi yang diperoleh dari pemanfaatan teknologi tersebut. Selain budaya, faktor sosial juga berpengaruh dalam penerapan informasi yang diperoleh dari faktor teknologi dalam pemberan intervensi gizi spesifik. Faktor sosial budaya dari orang yang berpengaruh atau pengambil keputusan (orang tua) yang mempengaruhi pemberian intervensi gizi spesifik 
dalam penelitian kali ini karena pada penelitian ini responden sangat menghargai arahan dari orang tua meskipun arahan tersebut bertentangan dengan kesehatan. Hal ini sesuai dengan penelitian (12) yang mengatakan bahwa faktor sosial berkaitan dengan internalisasi individu dan referensi kelompok budaya berhubungan dengan individu dalam pemanfaatan teknologi informasi.

Teknologi adalah suatu alat yang banyak digunakan oleh manusia yang memiliki efek positif dan negative seiring dengan kemajuan yang berkembang pesat dalam bidang teknologi. Teknologi informasi komunikasi adalah suatu alat perangkat yang mengabungkan aspek sosial yang memungkinkan setiap individu dapat mendapatkan, mengirimkan, dan saling bertukar informasi dengan individu-individu lainya. Namun, tidak semua orang bisa dan mampu bersentuhan langsung dengan teknologi canggih. Dengan kata lain, hanya sebagian orang yang mampu menggunakan teknologi (13)

Faktor lain yang membuat pemanfaatan teknologi cukup tetapi dalam pemberian intervensi spesifik negatif pada penelitian ini adalah sikap dari tenaga kesehatan yang belum melaksanakan deteksi dini stunting dengan melakukan pengukuran tinggi badan tiap kali poyandu. Selain itu, edukasi atau penyuluhan tentang stunting dan pencegahan stunting belum dilakukan. Namun, edukasi tentang ASI eksklusif, edukasi tentang pemberian kolostrum dan pemberian makanan bergizi pada anak dan juga kemudahan akses dalam pencegahan dan pengobatan penyakit infeksi seperti diare sudah dilakukan oleh petugas kesehatan. Pemanfaatan teknologi kesehatan dipengaruhi oleh sikap tenaga kesehatan, serta minat masyarakat. Hal ini sesuai dengan pendapat (14) yang mengatakan bahwa pemanfaatan teknologi kesehatan dipengaruhi oleh akses terhadap teknologi informasi, askses pada media dan pers, akses pada alat elektronik di lingkungan, dan akses pada pelayanan kesehatan.

Peneliti beranggapan bahwa pemanfaatan teknologi yang cukup namun kurang dalam pemberian intervensi gizi spesifik ini disebabkan kurangnya kesadaran responden dalam pemanfaatan pelayanan kesehatan dan faktor ekonomi. Ibu lebih memilih untuk bekerja dari pada membawa anaknya ke posyandu. Pemerintah melalui puskesmas telah melakukan upaya pencegahan stunting yaitu dengan menyediakan fasilitas dalam pemanfaatan teknologi pencegahan stunting seperti adanya posyandu, pemberian imunisasi secara secara geratis, pemberian obat cacing tiap 6 bulan sekali, sehingga anak tidak mendapatkan imunisasi dasar secara lengkap, tidak mendapatkan obat cacing, serta tidak mendapakan makanan tambahan dari peerintah yang diberikan secara rutin di posyandu. Hal tersebut sesuai dengan pendapat (15) teknologi kesehatan adalah sarana prasarana yang memungkinkan individu untuk memilih atau mendapatkan penawaran yang menyelesaikan masalah dalam pelayanan kesehatan.
4.2 Faktor Religius dan Filosofi dengan pemberian intervensi gizi spesifik

Hasil analisi dalam penelitian ini menunjukan bahwa setengah dari responden $(50,4 \%)$ memiliki faktor religious dan filosofi yang tidak mendukung dalam pemberian intervensi gizi spesifik yang negatif. Respoden yang memiliki faktor religious dan filosofi yang baik, sebanyak setangah dari jumlah responden lainya $(49,6 \%)$ mempunyai faktor religious dan filosofi yang mendukung dalam pemberian gizi spesifik. Responden yang mempunyai faktor religious dan filosofi yang tidak mendukung mempunyai hasil cenderung kurang dalam pemberian intervensi gizi spesifik. Namun, responden yang mempunyai faktor religious dan filosofi yang mendukung cenderung baik dalam pemberian intervensi gizi spesifik. Hasil uji statistik menunjukan tidak ada hubungan yang signifikan anata faktor religious dan filosofi dalam pemberian intervensi gizi spesifik.

Hal ini sesuai tidak sesuai dengan penelitian (16) yang mengatakan bahwa faktor religius dan filosofi berhubungan dengan perilaku seseorang. Suku Madura yang mempunyai tiga dimensi dalam religious. Dimensi tersebut adalah dimensi pengalaman mengenai perasaan tenang ketika melakukan tindakan yang religius. Dimensi pengetahuan agama, mengenai sebuah keyakinan dan kepercayaan yang digambarkan dengan tradisi. Dimensi kondekuensi, mengenai apa yang akan menjadi dampak setelah melakukan tindakan religious, antar dampak buruk dan baik (17).

Pada penelitian ini responden yang mempunyai faktor religious dan filosofi yang menguntungkan maupun yang tidak menguntukan tidak mempunyai perpedaan jumlah yang banyak. Hal ini dikarenakan masih banyak masyarakat Madura yang beranggapan mendapat ketenangan ketika melaukan sesuatu yang mereka yakini benar meskipun pada kenyataanya tidak menguntungkan bagi kesehatan. Tetapi sebagian yang lain Suku Madura sudah mulai untuk meninggalkan tradisi yang diyakini tersebut. Hal ini terjadi karena terdapat negosiasi budaya religius dan filosofi yang disepakati semua pihak sehingga pelayanan kesehatan yang diterima ibu diterima baik kepada ibu sehingga tercipta perilaku positif dalam pemberian gizi anak (18).

Pada penelitian kali ini responden yang mempunyai faktor religious dan filosofi yang tidak menguntungan lebih banyak meski tidak signifikan. Hal tersebut dikarenakan religiusitas ibu lebih mempengaruhi perilaku ibu dalam merawat bayi. Ibu dalam responden penelitian ini cenderung tidak tenang ketika hanya memperikan ASI eksklusif saja selama 6 bulan, dan masih ragu dalam memberikan imunisasi kepada anak karena takut anaknya rewel dan masih beranggapan anak sudah mempunayai daya tahan tubuh dari Tuhan. Hal di atas sesuai dengan teori transcultural nursing (19), religious memberiakn motivasi yang kuat untuk menempatkan kebenaran diatas segalanya, bahkan diatas kehiduan sendiri dan menyebabkan seseorang mempunyai 
sikap rendah hati dan membuka diri. Religious dan filosofi memliputi adanya agama yang dianut, cara pendang terhadap penyakit dan cara pengobatan atau kebiasaan agama yang mempunyai efek positif terhadap kesehatan.

\subsection{Faktor Dukungan Sosial dan Keluarga dengan Pemberian Intervensi Gizi Spesifik}

Hasil analisis dalam penelitian ini menunjukan bahwa sebagian besar ibu memiliki dukungan sosial yang cukup akan tetapi cenderung negatif dalam pemberian intervensi gizi spesifik. Dukungan sosial ini meliputi dukugan sosial berupa ungkapan empati, kepedulian, dan perhatian terhadap orang bersangkutan, dukungan berupa penghargaan, dukungan penghagaan, dukungan informatif, dan dukungan instrumental. Faktor dukungan sosial dan keluarga merupakan faktor yang paling berpengaruh terhadap pemberian intervensi gizi spesifik di wilayah kerja Puskesmas Galis Bangkalan.

Penelitian ini sesuai dengan (20) yang mengatakan bahwa keluarga memiliki peran penting dalam membentuk budaya dan perilaku kesehatan. Beberapa peneliti menyebutkan dukungan keluarga memimiliki hubungan dalam pemberian ASI dan juga pemberian Pola makan kepada anak. Semakin keluarga mendukung maka motivasi ibu dalam perawatan anak seperti pemberian ASI dan pola makan yang baik juga semakin baik (21), (22), (23) (10). Responden yang mempunyai dukungan sosial dan keluarga cukup belum tentu baik dalam pemberian intervensigizi spesifik. Hal tersebut dikarenakan karena budaya yang ada dalam keluarga yang tidak menguntungkan bagi kesehatan tetapi masih tetap diikuti.

Dukungan sosial adalah kemampuan keluarga dan masyarakat untuk menyediakan waktu, perhatiaan dukungan dalam bentuk fisik mental, dan sosial. Dukungan sosial meliputi perhatian atau dukungan keluarga terhadap ibu dalam pemberian makanan, rangsangan psikososial dan praktek dalam kesehatan bayi (24). Menyusui merupakan salah satu yang menunjang kesehatan bayi. Ibu yang sedang menyusui memiliki perasaan bersalah, merasa gagal saat tidak bisa menyusui anaknya dengan baik. Untuk itu perlu dukungan emosional dari keluarga (25). Setiap anggota keluarga memiliki beberapa peran dalam keluarga antara lain sebagai motivator, educator, dan fasilitator.

Kepala keluarga atau suami berperan penting di dalam suatu keluarga termasuk memberika motivasi, edukasi, dan memfasilitasi istri ketika memberikan makanan kepada anak. (26). Dalam penelitian ini, anggota yang berpengauh dalam perawatan anak termasuk dalam hal pemberan intervensi gizi spesifik adalah anggota keluarga yang dituakan yaitu nenek. Karena nenek dianggap sudah berpengalaman dalam perawatan anak. Tetapi, orang tua pada suku Madura masih mengikuti cara perawatan anak atau tradisi dalam perawatan anak yang tidak menguntungkan bagi kesehatan dan masih tetap diturunkan kepada generasi selanjutnya.
Penelitian ini sesuai dengan penelitian (27), yang mengatakan bahwa dukungan sosial masih terikat oleh kebiasaan, adat istiadat, maupun kepercayaan dari keluarga dan masyarakat pada daerah tersebut, sehingga berpengaruh dalam pemberian intervensi gizi spesifik yang dilakukan oleh ibu. Pada penelitian ini meskipun dukungan keluarga cukup baik, tetapi kurang dalam pemberian intervensi gizi spesifik. Peneliti beranggapan bahwa hal tersebut dikarenakan segala bentuk perawatan bayi sepenuhnya mengikuti apa yang disampaikan keluarga. Kebiasaan, adat istiadat, maupun kepercayaan dari keluarga yang kurang mendukung kesehatan anak menyebabkan pemberian intervensi gizi spesifik yang tidak baik. Faktor sosial dan keluarga dalam penelitian ini yang kurang mendukung antara lain keluarga masih meyakini pemberian makanan pendamping ASI sebelum usia 6 bulan seperti memberikan pisang, air kelapa, nasi halus membuat anak semakin kenyang, sehat dan tidak rewel.

\subsection{Faktor budaya dan gaya hidup dengan pemberian intervensi gizi spesifik}

Hasil analisis dalam penelitian ini menunjukan bahwa sebagian sebagian besar responden mempunyai faktor nilai budaya dan gaya hidup yang tidak mendukung dalam pemberian intervensi gizi spesifik. Responden yang mempunyai faktor nilai budaya dan gaya hidup yang tidak mendukung bagi kesehatan cenderung negatif dalam pemberian intervensi gizi spesifik sebagai upaya pencegahan stunting untuk anak. Dari hasil Analisa faktor nilai budaya dan gaya hidup merupakan faktor yang berpengaruh dalam pemberian intervensi giziz spesifik bagi anak di wilayah kerja Puskesma Galis.

Penelitian ini sesuai dengan penelitian (16) dan (10) yang menyebutkan bahwa nilai budaya dan gaya hidup berhubungan dengan perilaku seseorang termasik memberian gizi anak. Menurut (11) pada Teori transcultural nursing menyatakan bahwa kebudayaan adalah keseluruhan yang kompleks, yang di dalamnya terkandung ilmu pengetahuan, kepercayaa, kesenian, moral, hukum, adat istiadat, dan kemampuan lain, serta kebiasaan yang di dapat oleh manusia sebagai masyarakat. Kebiasaan yang terbentuk berdasarkan kebudayaan dapat mempengaruhi status gizi dan menyebabkan terjadinya malnutrisi (28). Pada penelitian ini responden yang mempunyai bayi masih dibatasi oleh budaya, kebiasaan, adat istiadat, maupun kepercayaan yang telah menjadi adat istiadat kehidupan suatu wilayah, dimana sebagian besar faktor nilai budaya dan gaya hidup yang dimiliki responden cenderung tidak menguntungkan bagi kesehatan.

Budaya adalah kepercayaan dan nilai-nilai yang dianut oleh masyarakat, dalam masyarakat terdapat beberapaorang yang berpengaruh dan menjadi panutan serta dihormati pendapatnya (29). Sebagia besar responden pada penelitian ini masih meyakini dan sangat menghormati serta menjalankan anjuran 
atau perinth dari orang penting di lingkunaganya (misalnya suami, orang tua, mertua, tetangga, tokoh agama, dan tokoh masyarakat) yang mempengaruhi pemberian intervensi gizi spesifik pada anak. Budaya merupakan pandangan hidup dari seseorang individu atau kelompok dengan mengacu pada nilai, keyakinan, norma, pola, dan praktik yang dipelajari, dibagiakan, dan diwariskan avatar generasi (30). Biasanya orang tualah yang mengajarkan nilai budaya dan gaya idup mereka secara turn menurun kepada anaknya, termasuk mengajarkan nilai budaya dan gaya hidup dalam masyarakat.

Pada penelitian ini nilai budaya dan gaya hidup yang dimiliki responden diantaranya memberikan air kelapa pada anak baru lahir dengan tujuan agar bayi sehat dan kuat, memberikan pisang halus pada bayi sebelum usia 6 bulan supaya anak tidak rewel, kebudayaan untuk mengkonsumsi banyak nasi dan sedikit mengkonsumsi protein. Hal tersebut sesuai degan penelitian (31) yaitu suku Madura mempunyai kebiasaan dalam merawat anak diantaranya budaya suku madura lebih banyak mengkonsumsi nasi dan sedikit jenis sayuran dan sangat jarang mengknsumsi telur, susu, dan daging, dan tradisi pemberian makanan dini denganistilah lotek, made, serta ro'moro' atau pemberian air kelapa pada bayi baru lahir dengan ujuan supaya anak cepat besar dan kuat. Sebagian responden juga tidak memberikan kolostrum karena dianggap ASI keruh dan tidak memberikan ASI selana 2 tahun karena menganggap anak sudah besar tidak perlu ASI.

Berdasarkan penjelasan diatas, bahwa nilai budaya yang tidak mendukung sehingga pemberian gizi spesifik cenderung negatif disebabkan karena responden selalu mengikuti anjuran dari orang tua atau yang lebih tua meskipun anjuran tersebut merugikan bagi kesehatan. Responden menganggap orang yang lebih tua sudah berpengalaman dalam perawatan anak sehingga berdampak negatif pada pemberian intervensi gizi spesifik dalam upaya pencegahan stunting. Negosiasi budaya merupakan intervensi dan implementasi keperawatan yang teapat perlu dilakukan, untuk itu membantu ibu beradaptasi terhadap budaya tertentu yang lebih menguntungkan dan mengacu pada kesehatan (32).

4.5 Faktor Politik dan Legal dengan pemberian intervensi gizi spesifik intervensi gizi spesifik

Hasil analisis dalam penelitian ini menunjukan bahwa sebagian sebagian besar responden mempunyai faktor politik dan legal yang mendukung dalam pemberian intervensi gizi spesifik. Responden yang mempunyai faktor politik dan legal yang mendukung bagi kesehatan cenderung positif dalam pemberian intervensi gizi spesifik sebagai upaya pencegahan stunting untuk anak. Dari hasil Analisa faktor politik dan legal menunjukan tidak terdapat hubungan antara faktor politik dan legal dalam pemberian intervensi giziz spesifik di wilayah kerja Puskesmas Galis Madura.

Hal ini tidak sejalan dengan (33), yang menyebutkan bahwa kebijakan yang terdapat di masyarakat sangat pempengaruhi perilaku seseorang. Pada penelitian ini kebanyakan responden memiliki politik yang mendukung dengan pemberian gizi spesifik. Politik dan legal yang dimaksud adalah tidak adanya larangan dalam pemberian intervensi gizi yang meliputi tidak adanya larangan pemberian kolostrum, ASI eksklusif, ASI sampai 23 bulan didampingi makanan pendamping, penyediaan obat cacing dan suplemen zink, pemberian zat besi dan imunisasi lengkap, pencegahan dan pengobatan diare.

Ada faktor politik dan Legal di wilyah kerja Puskesma Galis yang berkaitan dengan pemberian intervensi gizi spesifik. Salah satunya adalah dalam tujuan SDG's kedua yaitu pada tahun 2030 mengakhiri kelaparan dan menjamin akses pangan yang aman, bergizi, dan mencukupi bagi semua orang, khususnya masyarakat miskin dan rentan termasuk bayi, di sepanjang tahun dan pada tahun 2030 mengahiri segala bentuk malnutrisi, termasuk mencapai target internasional 2025 untuk penurunan stunting dan wasting pada balita dan mengatasi kebutuhan gizi remaja perempuan, wanita hamil dan menyusui, serta lansia (5). Dari tujuan SDG's tersebut pemerintah telah mebuat kebijakan berupa memberiakan makanan tambahan berupa biscuit yang dibetikan saat posyandu, pemberian obat cacing setiap 6 bulan sekali. Tidak ada peraturan adat pada penelitian yang tidak mendukung dalam pemberian intervensi gizi spesifik. Sehingga pada penelitian ini didapatkan bahwa faktor politik dan legal sebagian responden mendukung dalam pemberian intervensi gizi spesifik.

Menurut Teori transcultural nursing oleh (11) menjelaskan bahwa kebijakan dan peraturan rumah sakit atau instansi kesehatan dan norma yang berlaku di masyarakat akan mempengaruhi kegiatan seharihari individu maupun kelompok dan juga dalam pelaksanaan asuhan keperawatan berbasis budaya. Namun pada penelitian ini juga belum ada kebijakan dan peraturan adat suku Madura yang dikeluarkan tokoh masyarakat, pemangku adat, dan norma di wilayah kerja Puskesmas Galis yang mendukung pencegahan stunting yaitu dengan pemberian intervensi giziz spesifik, akan tetapi sebagian responden sudah mendapat anjuran dari tenaga kesehatan mengenai pemberian ASI eksklusif sebagai salah satu pencegahan stunting.

Berdasarkan uraian di atas, faktor politik dan legal yang dikeluarkan pemerintah mendukung pemberian intervensi gizi spesifik sebagai upaya pencegahan stunting. Tidak ada aturan adat, kebijakan adat, dan Norma yang melarang juga dalam pemberian intervensi gizi spesifik. Namun tidak ada juga kebijakan adat, aturan adat, dan Norma yang dikeluarkan oleh tokoh masyarakat yang mendukung pemberian intervensi gizi spesifik sebagai upaya pencegahan stunting.

4.6 Faktor Ekonomi dengan pemberian intervensi gizi spesifik 
Hasil analisis dalam penelitian ini menunjukan bahwa sebagian responden status sosial ekonomi berada dibawah UMR yaitu Rp 1.800.000,00. Responden yang mempunyai status ekonomi tinggi cenderung negatif dalam pemberian intervensi gizi spesifik sebagai upaya pencegahan stunting untuk anak. Dari hasil Analisa faktor ekonomi menunjukan tidak terdapat hubungan antara faktor ekonomi dalam pemberian intervensi giziz spesifik di wilayah kerja Puskesmas Galis Madura.

Pendapatan Keluarga merupakan jumlah uang yang dihasilkan dan jumlah uang yang akan dikeluarkan untuk membiayai keperluanrumah tangga dalam satu bulan. Pendapatan keluarga yang mencukupi akan menunjang perilaku anggota keluarga untuk mendapatkan pelayanan kesehatan keluarga yang lebih memadai (34). Penelitian ini bertentangan dengan penelitian yang diakukan oleh (35) yaitu pendapatan keluarga yang rendah merupakan faktor yang berhubungan dengan kejadian stunting pada anak usia 6-24 bulan. Dengan penghasilan rendah, keluarga akan mempunyai Batasan dan kesulitan dala mencukupi kebutuhan sehari-hari. Dan juga bertentangan dengan penelitian (16) dan (10) yang menyebutkan bahwa faktor ekonomi berhubungan dengan pemberian gizi pada balita, apabila ekonomi rendah maka pemberian gizi pada anak tidak tepat.

Sebagian besar ibu pada penelitian ini juga berprofesi sebagai ibu rumah tangga yang tidak memiliki penghasilan namun memiliki pemberian intervensi gizi yang baik untuk anak. Hal ini dikarenakan ibu rumah tangga biasanya memiliki pola asuh terhadap tumbuh kembang balita yang baik dari pada ibu yang memiliki pekerjaan diluar rumah, karena ibu dapat lebih fokus untuk mengasuh anak (36). Bentuk keluarga yang dimiliki responden dalam penelitian ini lebih banyak keluarga besar yang berjumlah lebih dari lima orang dalam satu rumah. Jumlah anggota keluarga mempengaruhi penyediaan dan distribusi pangan dalam keluarga. Kualitas konsumsi pangan semakin buruk pada rumah tangga yang memiliki jumlah anggota keluarga yang relatif banyak (37). Hal ini beretntangan dalam penelitian ini, karena meskipun jumlah anggota keluarga lebih banyak Namun pemberian intervensi gizi baik pada anak.

Tingkat sosial ekonomi berkaitan dengan daya beli keluarga. Kemampuan keluarga untuk membeli hahah makanan tergantung pada besar kecilnya pendapatan keluarga,harga hahah makanan, serta tingkat pengelolaan sumber daya lahan dan pekrangan (38). Tingkat pendapatan seseorang akan berpengaruh terhadap Jenis dan jumlah hahah pangan yang dikonsumsinya (39). Menurut (40) keterbatasan penghasilan keluarga turut menentukan mutu maknan yang dikelola setiap harinya baik dari segi kualitas maupun jumlah makanan. Kemiskinan yang berlangsung lama mengakibatkan rumah tangga tidak mampu untuk memenuhi kebutuhan pangan yang menyebabkan tidak tercukupinya gizi untuk pertumbuhan anak. Hal diatas tidak sejalan dengan penelitian ini. Status sosial ekonomi yang rendah bukan berarti bahwa keluarga tidak bisa memenuhi kebutuhan gizi bagi anak.

Sumber gizi bagi anak tidak semua mahal dan tidak terjankau bagi ekonomi rendah. Seperti number zink dan fe bisa didapatkan pada protein nabati seperti dalam kacang-kacangan dan sayur-sayuran. Selain itu juga terdapat pada sumber hewani seperti ikan laut, tongkol, bandeng yang masih terjangkau bagi masyarakat yang ekonomi rendah. Seperti pendapat (41)) yang menyebutkan bahwa konsumsi sayur-sayuran yang mengandung vitamin, mineral dan serat merupakan salah satu indicator sederhana dalam mewujudkan gizi seimbang. Pemerintah juga telah memberikan fasilitas bagi pencegahan stuning secra geratis melalui puskesmas dalam program posyandu balita yaitu seperti pemberian imunisasi dasar secara geratis, pemberian obat cacing secara geratis tiap 6 bulan sekali, serta pemberian makanan tambahan berupa biskuit. Hal tersebut dapat dibutikan jika tidak adanya hubunganya antara faktor ekonomi dengan pemberian intervensi gizi spesifik pada anak usia 6-24 bulan di wilayah kerja Puskesmas Galis.

\subsection{Faktor Pendidikan dengan pemberian intervensi gizi spesifik}

Hasil analisis dalam penelitian ini menunjukan bahwa sebagian besar responden mempunyai tingkat pendidikan sekolah dasar (SD). Responden yang mempunyai tingkat pendidikan SD cenderung positif dalam pemberian intervensi gizi spesifik sebagai upaya pencegahan stunting untuk anak. Dari hasil Analisa faktor pendidikan menunjukan tidak terdapat hubungan antara faktor politik dan legal dalam pemberian intervensi giziz spesifik di wilayah kerja Puskesmas Galis Madura.

Penelitian ini sejalan dengan penelitian dari (42) bahwa pendidikan ibu tidak berhubungan dengan kejadian stunting. Ibu yang memiliki pendidikan tinggi biasanya bekerja dan akan menyebabkan berkurangnya waktu ibu dalam mengasuh serta memberikan perhatian anak terhadap pemberian makan dan perawatan anak yang Kemudian berpengaruh pada pertumbuhan dan perkembangan anak. Menurut (43) status pendidikan ibu menjadi prediktor penting stunting di pedesaan Guatemala, namun pendidikan ibu juga dapat dipengaruhi oleh petugas kesehatan yang dapat memberikan informasi kesehatan kepada ibu Namun berbeda dengan penelitian (44) bahwa terdapat hubungan bermakna antara pendidikan ibu denga kejadian stunting pada balita. Ibu yang mempunyai pendidikan tingi cenderung untuk memberikan gizi yang lebih untuk kesehatan anakanya. Selain it ibu yang berpendidikan tinggi akan lebih baik dalam menggunakan strategi kesehatan seperti memberikan ASI eksklusif, memberikan imunisasi, dan sadar akan gizi anak. Responden dengan tingkat pendidikan rendah cenderung akan lebih kuat mempertahankan tradisi 
dan budaya dengan makanan sehingga sulit menerima informasi baru (30).

Dilihat dari umur ibu, pada penelitian ini umur ibu sebagian besar adalah 23-35 tahun. Faktor umur merupakan faktor secara tidak langsung memengaruhi status gizi balita, faktor umur kehamilan ibu ini secara langsung mempengaruhi kesehatan reproduksi pada kehamilan ibu, yaitu menetukan tercapainya potensi genetic yang optimal, yaitu faktor prenatal dan postnatal. Faktor umur sangat mempengaruhi tingkat pengetahuan ibu tentang gizi, jadi jika umur bu masih muda maka belum memiliki banyak pengetahuan yang cukup tentang gizi, baik pada saat ibu hamil maupun setelah. (45). Namun pada penelitian ini meskipun umur ibu sebagian besar masih muda tapi baik dalam pemberian gizi pada anak.

Teori Transcultural nursing menyebutkan bahwa perilaku kesehatan dibentuk dari berbagai faktor yang bekerja bersama-sama (11). Pendapatan akan mempengaruhi gaya hidup keluarga. Keluarga yang memiliki status ekonomi baik akan mempraktikan gaya hidup yang mean dan lebih konsumtif dibandingkan dengan keluarga yang status ekonominya rendah (24). Pada penelitian ini meskipun ibu memiliki jenjang pendidikan yang rendah, namun tidak berarti memiliki pengetahuan yang rendah terhadap perawatan anak dalam pencegahan stuning. Hal ini didukung dengan pendapat (46) yang mengatakan bahwa seseorang yang berpendidikan rendah bukan berarti berpengetahuan rendah. Peningkatan pengetahuan tidak hanya diperoleh dari pendidikan formal saja, akan tetapi dapat diperoleh dari pendidikan non formal. Pendidikan non formal yang ada pada penelitian ini adalah yang didapatkan responden melalui petugas kesehatan.

Sebagian besar jenjang pendidikan terbanyak responden adalah SD. Hal ini disebabkan adanya keterbatasan ekonomi keluarga responden sehingga hanya mampu menyekolahkan anaknya sampai SD. Peneliti beranggapan bahwa sebagian besar responden mempunyai pemberian intervensi gizi yang postif tersebut tidak berdasarkan jenjang pendidikan yng telah ditempuh. Banyak hal dalam pendidikan non formal yang dapat membuat pengetahuan menjadi baik dalam perawatan anak pencegahan stunting. Misalnya informasi dari bidan desa dan dari tenaga kesehatan lainya di wilayah kerja puskesmas Galis.

\section{KESIMPULAN}

Faktor dukungan sosial dan keluarga memiliki hubungan yang signifikan dengan pemberian intervensi gizi spesifik. Dukungan sosial ini meliputi dukugan sosial berupa ungkapan empati, kepedulian, dan perhatian terhadap orang bersangkutan, dukungan berupa penghargaan, dukungan penghagaan, dukungan informatif, dan dukungan instrumental. Kebudaayan yang paling berpengaruh pada penelitian ini adalah dukungan informatif berupa nasehat orang tua yang masih mengikuti adat kebudayaan turun temurun padahal budaya tersebut bertentangan dengan kesehatan. Kebanyakan Masyarakat Madura sangat mempercayai dan mengikuti nasehat dari orang tua sepeti nenek, orang tua, dan mertua. Dukungan keluarga yang cukup tidak membuat pemberian intervensi gizi spesifik baik karena kebudaan yang dipunyai keluarga tidak mendukung pemberian gizi spesifik sudah diangap benar oleh keluarga dan dilakukan secara terus menerus sehinga tidak mendukung dalam pemberian intervensi gizi spesifik pada anak.

Faktor nilai budaya dan gaya hidup memiliki hubungan yang signifikan dengan pemberian gizi spesifk. Nilai budaya dan gaya hidup yang tidak mendukung membuat pemberian intervensi gizi spesifik yang negatif. Ha ini dikarenakan ada kebudayaan Madura seperti memberikan makanan pendamping ASI sebelum 6 bulan, tidak diberikanya ASI eksklusif, tidak melanjutkan ASI sempai usia 2 tahun, dan ada sebagian masyarakay yang tidak memberikan imunisasi kepada anaknya yang bertolak belakang dengan ilmu kesehatan.

Petugas kesehatan disarankan untuk memberikan healt education kepada ibu dan keluarga (orang tua) mengenai pemberian intervensi gizi spesifik dalam pencegahan stunting. Selain itu edukasi juga perlu diberikan kepada tohkoh masyarakat atau orang yang berpengaruh dalam kebudayaan masyarakat untuk lebih baik lagi dalam melakukan perawatan anak khususnya pemberian intervensi gizi spesifik dalam upaya pencegahan stunting.

\section{UCAPAN TERIMA KASIH}

Kami mengucapkan terima kasih kepada Kepala Puskesmas Galis Banhkalan Madura untuk izin dan penerimaan kami untuk mengambil data sebagai bahan penelitian dan semua responden yaitu masyarakat Kecamatan Galis yang telah bersedia menjadi responden.

\section{DAFTAR PUSTAKA}

1. Sandjojo PE. Buku saku Desa dalam Penanganan Stunting. Jakarta: Keenterian Desa, Pembangunan Daerah Tertinggal, dan Transmigrasi; 2017. 42 p.

2. Kusharisupeni. Gizi Dalam Daur Kehidupan (Prinsip-Prinsip Dasar). Jakarta: PT Raja Grafindo Persada; 2008.

3. Jahari AB. Penurunan Masalah Balita Stunting. Jakarta: Persatuan Ahli Gizi Indonesia (PERSAGI); 2018. 46 p.

4. Riskesdas. RISET KESEHATAN DASAR. Ris Kesehat Dasar 2013. 2013;

5. Sumekar S, Haryadi U. Sosialisasi Sustainable Development Goals (SDGs). In Jakarta: Perpustaknaan Nasional; 2016. p. 39.

6. Sjarif DR, Yuliarti K, Lestari ED, Sidiartha IGL, 
Nasar MM SS. Rekomendasi Praktik Pemberian Makan Berbasis Bukti pada Bayi dan Batita di Indonesia untuk Mencegah Malnutrisi. Rekom Dr Anak Indones. 2015;10-26.

7. Laksono A. Pedoman Perencanaan Program. Gerak Nas Percepatan Perbaikan Gizi dalam Rangka Seribu Hari Pertama Kehidup (Gerakan 100 HPK). 2012;10-7.

8. Adriani M, Wirjatmadi B. Pengantar Gizi Masyarakat. Jakarta: Kharisma Putra Utama; 2012.

9. Illaihi KR, Muniroh L. Gambaran Sosio Budaya Gizi Etnik Madura dan Kejadian Stunting Balita Usia 24-59 bulan di Bangkalan. J Nutr. 2016;11:135-43.

10. Firdhani, A E, R.G I. Pola Pemberian ASI, MP-ASI dan Status Gizi Anak Usia 1-2 Tahun pada Keluarga Etnis MAdura dan Etnis Arab(Studi di Puskesmas Pegiran dan Puskesmas Perak Timur Surabaya). Bul Penelit Sist Kesehat. 2015;90-9.

11. Leininger M. Culture Care Theory: A Mayor Kontribution to Advance Transcultural Nursing Knowledge and Parcties. Transcult Nurs. 2002;13:189.

12. Rahmawati D. Analisis Faktor Faktor yang Berpengaruh Terhadap Pemanfaatan Teknologi Informasi. J Ekon dan Pendidik. 2019;5(1):10718.

13. Wahid J. Pengaruh Teknolo Komunikasi terhadap Perilaku Manusia. J Progr Stud Pendidik Bhs dan Sastra Indones Univ Wiralodra, Indramayu. 2016;

14. Melo L.P.D. Sunrise Model : A Contribution to the Teaching of Nursing Consultation in Collective Healt. Am J Nurs Res. 2013;1:20-3.

15. Motee A and JR. Importance of Breast Feeding and Complementary Feeding Among Infants. Curr Res Nuyrition Food Sci. 2014;2:56-72.

16. Narendra HY. Analisis Faktor yang Berhubungan dengan Pemberian ASI Eksklusif Berbasis Transcultural Nursing di Puskesmas Sreseh Kabupaten Sampang. Universitas Airlangga; 2017.

17. Purwaningsih, Ni Ketut Alit A, Esti Y, Mira T C. Atenatal Class Services Standart Complicated of Village Midwife in East Java Province. 2013;295300.

18. Mn, C. and Sebean M. Transcultural Nursing in Zimbia: A Challengge for the21 st Century. Ann Nurs Res Pr. 2017;2:1-4.

19. Leininger M. Culture Care Theor : A Ma or contri ution to Advance Transcultural ur sing Knowladge and Practies. J Transcult. 2002;13:189.
20. Friedman M, Bowden V, Jones E. Buku Ajar Keperawatan Keluarga: Riset, Teori, dan Praktik. 5th ed. Yani S, Hamid, editors. Jakarta: EGC; 2010.

21. Ramadani M, Hadi EN. Dukungan Suami dalam Pemberian ASI Eksklusif di Wilayah Kerja Puskesmas Air Tawar Kota Padang, Sumatera Barat. Kesmas Natl Public Heal J. 2010;4(6):269.

22. Anggorowati, Nuzulia F. Hubungan antara dukungan keluarga dengan pemberian ASI eksklusif pada bayi di Desa Bebengan Kecamatan Boja Kabupaten Kendal. J Keperawatan Matern. 2013;1(3):1-8.

23. GAY. Pemberian ASI Eksklusif dan Faktor-faktor yang Mempengaruhi. Gizi. 2014;20(4):15-26.

24. Jang $M K$ et al. Belief factor associated with breastfeeding intentions of single woman: Based on the theory. J Nutr Heal. 2017;50 (3):284.

25. Debevec AD, Evanson TA. Improving Breastfeeding Support by Understanding Women's Perspectives and Emotional Experiences of Breastfeeding. Nurs Womens Health. 2016;20(5):464-74.

26. Efendi, Makhfudli. Keperawatan Kesehatan Komunitas: Teori dan Praktek dalam Keperawatan. Jakarta: Salemba Medika; 2009.

27. Laura, H.c and Santos I. Breastfeeding Pattern an Duration and Post-Partum Maternal Weight Retention. Clin Mother Child Heal. 2016;6-11.

28. Booth, DA dan Booth P. Targeting Cultural Changes Supporti e of The Healthiest le Patterns. Appetite. 2011;56:210-21.

29. Micklewright D, Northeast L, Parker P, Jermy M, Hardcastle J, Davison R, et al. The cardiac rehabilitation inventory a new method of tailoring patient support. J Cardiovasc Nurs. 2016;31(2):175-85.

30. Munawara, Yasak, E. M . Dewi SI. Budaya Pernikahan Dini Terhadap kesetaraan Gender Masyarakat MAdura. J Ilmu Sos dan Ilmu Polit. 2015;4:426-31.

31. Hidayat AA., et al. Pengembangan Model Keperawatan Berbasis Budaya (Etnonursing) Pada Keluarga Etnis Madura. Universitas Muhamadiyah Surabaya; 2013.

32. Fatonah s. Analisi Faktor yang berhubungan dengan Animea pada Ibu Hamil Berbasis Transcultural Nursing di wilayah kerja Puskesmas Socah. J Nurs Perpstakaan Univ Airlangga. 2016;

33. Yunitasari, E., Pradani, R. and S. Early Marriage Based on Trabscultural Nursing Theory in Kara Village Sampang. J Ners. 2016;164-9. 
34. Manurung JJ, Adler H. Manurung. Ekonomi Keuangan dan Kebijakan Moneter. Pertama. Jakarta: Salemba Empat; 2009.

35. Nadhiroh K. dan S. Faktor yang Berhubungan dengan Kejadian Stunting Pada Balita. J Media Gizi Indones. 2015;13-9.

36. Septiana, R., Djanah, R.S.N., Djamil MD. Hubungan antar pola pemberian makanan pendamping asi dan status gizi balita usia 6-24 bulan diwilayah kerja Puskesmas Gedongtengteng Yogyakarta. J Kesehat Masy. 2010;4:118-24.

37. Ariningsih, E., Rachman HPS. Strategi peningkatan ketahanan pangan rumah tangga rawan pangan. Analisis Kebijakan Pertanian, 6(3), 239-255. 2008.

38. Fikawati $\mathrm{S}$ dan A. Kajian Impementasi dan Kebijakan Air Susu Ibu eksklusif dan Inisiasi Menyusui Dini di Indonesia. Makara Kesehat. 2010;17-24.

39. Fauzia D i. Pola Konsumsi Pangan dan Status Gizi Balita yang Tinggal di Daerah Rawan Pangan di Kabupaten Banjarnegara, Jawa Tengah. Institut
Pertaian Bogor. Institut Pertanian Bogor; 2009.

40. Proverawati A. \& Rahmawati E. Kapita Selekta ASI dan Menyusui. Yogyakarta: Nuha Medika; 2010.

41. Kemenkes. Kementerian $\{$ Kesehatan $\}$ Republik\} \{Indonesia\}. In Kementeria Kesehatan Republik Indonesia; 2017.

42. Nasikhah R. Faktor Risiko Kejadian Stunting Pada Balita. Univ Diponegoro. 2014;1:1-27.

43. Sereebutra P, Solomons N, Aliyu MH, Jolly PE. Sociodemographic and environmental predictors of childhood stunting in rural Guatemala. Nutr Res. 2006;26(2):65-70.

44. Rahayu A, Khairiyati L. Resiko Pendidikan Ibu anak stunting pada anak usia 6-23 bulan. 2014;37(Ci):129-36.

45. Liswati EMEY, Studi P, Gizi I, Kesehatan FI, Surakarta UM. Hubungan Karakteristik Ibu Dengan Status Gizi. 2016;

46. Notoadmodjo S. Kesehatan Masyarakat Ilmu dan Seni. In: Kesehatan masyarakat Ilmu dan Seni. Jakarta: Rineka Cipta; 2011. 